\title{
A new Synbranchus (Teleostei: Synbranchiformes: Synbranchidae) from ilha de Marajó, Pará, Brazil, with notes on its reproductive biology and larval development
}

\author{
Sandra E. Favorito*, Angela M. Zanata**, and Maria I. Assumpção***
}

Synbranchus lampreia, new species, is described from rio Goiapi, Marajó Island, Pará, northern Brazil. It differs from the other two described species of the genus by its color pattern, which consists of large roundish black blotches scattered over a light brown or yellowish ground pigmentation and presence of inconspicuous brown small spots distributed among the large dark spots. The species is further distinguished from S. marmoratus by a higher number of vertebrae and from $S$. madeira by a shorter post-anal length. Information about reproductive aspects is provided and larval stages are described and illustrated.

Uma espécie nova de Synbranchus é descrita do rio Goiapi, ilha de Marajó, Pará, norte do Brasil. Esta espécie distingue-se de suas duas congêneres pelo colorido do corpo, que consiste em manchas negras arredondadas distribuídas sobre coloração marrom clara ou amarelada e presença de pequenas manchas marrons relativamente inconspícuas distribuídas entre as grandes manchas escuras. A espécie difere ainda de $S$. marmoratus pelo elevado número de vértebras e de $S$. madeira pelo menor comprimento pós-anal. São apresentadas informações sobre aspectos reprodutivos, descrições e ilustrações de estágios larvais.

Key words: Neotropical, swamp eels, new species, reproductive strategies, larvae.

\section{Introduction}

The Synbranchidae, or swamp eels, a family of highly derived eel-like acanthomorphs, comprises 17 species arranged in four genera (Bailey \& Gans, 1998). Synbranchids occur in a variety of habitats including fresh and estuarine waters from Middle and South America, Cuba, to West Africa, Asia, and the Indo-Australian Archipelago (Nelson, 1994). Several species are well known for their amphibious habits and the presence of accessory air breathing organs (see e.g., Rosen \& Greenwood, 1976; Liem, 1987; Munshi et al., 1989a, b) that enable them to undertake overland excursions. The relative high resistance to salinity (Tyler \& Feller, 1996) permits members of the family to survive in diverse environments and possibly enables the group to have broad ecological and geographical distribution.
Neotropical species of Synbranchidae are included in two genera: Synbranchus and Ophisternon. Two species of Ophisternon are restricted to South and Central America and the four remaining ones occur in Africa, Australia, and Asia. Synbranchus is endemic to South and Central America and comprises only two recognized species, $S$. marmoratus and S. madeirae (Rosen \& Greenwood, 1976). According to Rosen $\&$ Greenwood (1976) the genus is defined by a series of characters, e.g., gill opening pore-like and flanked by deep folds and free from isthmus, pectoral girdle posteriorly displaced to the level of the fifth or sixth vertebra, and posttemporal bone reduced to a simple stalk without connection with supracleithrum. However, a detailed examination of large series of Neotropical synbranchids carried out by Favorito-Amorim

*Laboratório de Biodiversidade da Universidade Bandeirante de São Paulo - UNIBAN, Rua Cisplatina 660, apto. 12, Ipiranga, 04211-040 São Paulo, SP, Brazil. e-mail: sfavorito@terra.com.br

**Departamento de Zoologia, Instituto de Biologia, Universidade Federal da Bahia - UFBA, Rua Barão de Geremoabo s/n, Ondina, 40170290 Salvador, BA, Brazil. e-mail: a zanata@yahoo.com.br

***Laboratório de Ictiologia, Museu Paraense Emílio Goeldi, Av. Magalhães Barata 376, CP 399, 66040-170 Belém, PA, Brazil. 
$(1992,1998)$ revealed that the genus is not characterized by exclusive characters and needs a rediagnosis. The author pointed out that recently collected specimens do not fit properly in the available definition of Synbranchus. Also, the species level taxonomy of Synbranchus is very poor and the number of species to be recognized is yet to be defined.

Biological and reproductive aspects in synbranchids are also poorly studied, except by a few papers dealing with aspects of larval development and gas exchange in a few species. A detailed description of the development of $S$. marmoratus by Taylor (1913), including reproductive habits and larval development, represents the most extensive study dealing with these aspects within the family. Observations on breeding habits and larval development were also provided for the Asian synbranchids Monopterus albus (Wu \& Liu, 1942), M. cuchia (Banerj et al., 1981), and Ophisternon bengalense (Rangarajan \& Jacob, 1960). Liem (1981) analyzed larvae of Monopterus albus and described the active pectoral-fin mechanism and the countercurrent flow as adaptations to gas exchange during periods of critical hypoxia. Vascularization of the pectoral fin and capacity of larval respiratory organs were also studied by Munshi et al. (1989a) for Monopterus cuchia. The process of sex reversal in synbranchids, on the other hand, has been subject of a series of studies (e.g., Tao et al., 1993; Ravaglia et al., 1997). Synbranchus marmoratus, particularly, is known as a protogynous diandric fish (Lo Nostro \& Guerrero, 1996), with two different kind of males. Primary males develop directly as males while secondary males arise from the sex reversal of females (Sadovy \& Shapiro, 1987; Lo Nostro \& Guerrero, 1996).

Collecting efforts carried out by two of the authors (SFA and MIA) resulted in the capture of a distinctive form of Synbranchus along with eggs and larvae. One of these larvae (25.0 $\mathrm{mm}$ TL) was already studied by Britz et al. (2003), to evaluate the identity of the single pterygoid bone in Synbranchidae. We herein describe the new Synbranchus species, six developmental stages and also present notes on the reproductive biology, the habitat, the nest structure, and suggest the presence of parental care.

\section{Material and Methods}

Intensive fieldwork aiming to collect eggs, larvae, and adults of Synbranchus lampreia were performed in November 1995. Eggs and larvae were collected with small hand nets introduced into vertical tunnels to reach the small pools described in the item "Habitat and reproductive notes". The specimens captured were kept alive in plastic jars filled with water and later transported to the laboratory where they were transferred to a small continuously aerated aquarium. Observations of live larvae in the laboratory focused on the pattern of pectoral fin movement, directions of blood flow in this fin, and locomotory activity of specific larval stages. The specimens were then preserved at different stages of development, using $10 \%$ formalin, for a period of 12 hours, and subsequently transferred to $70 \%$ alcohol. Adults of S. lampreia were collected in the same nests, close to the area where eggs and larvae were deposited, using a fishhook baited with fresh fish. These specimens were fixed subsequently in $10 \%$ formalin. Sex of specimens was determined by gonad examination.

Specimens examined are deposited in the Museu de Zoologia da Universidade de São Paulo (MZUSP), Museu Paraense Emílio Goeldi (MPEG), American Museum of Natural History (AMNH), and National Museum of Natural History, Smithsonian Institution (USNM). All measurements were taken point to point with a dial caliper or ruler (for measurements longer than $200 \mathrm{~mm}$ ), on the left side of the specimens, whenever possible. Standard length and larval measurements are expressed in $\mathrm{mm}$. All other measurements of adults are expressed as percent of standard length, except subunits of the head, which are expressed as percent of head length and branchial opening width, which is expressed as percent of head width. Measurements and counts include: 1) total length, measured from tip of snout to tail tip; 2) post-anal length, from posterior border of anus to the tail tip; 3 ) head length, from dentary symphysis to posterior border of branchial opening; 4) head width, distance between lateral borders of head, at posterior border of branchial opening; 5) horizontal eye diameter, distance between anterior and posterior borders of orbit; 6) preorbital length, from anterior tip of snout to anterior border of orbit; 7) least interorbital width, short distance between dorsal borders of eyes; 8) mouth length, from dentary symphysis to posterior end of maxillary bone, with mouth closed; 9) branchial opening width, largest distance between posterior borders of branchial opening; (10) number of series of premaxillary teeth; (11) number of series of ectopterygoid teeth; (12) number of series of dentary teeth; (13) number of abdominal vertebrae (without haemal spine), counted from the anteriormost that articulates with cranium to the one articulating with the first caudal vertebra; (14) number of caudal vertebrae, includes all vertebrae with hemal spine; (15) total number of vertebrae, includes all abdominal and caudal vertebrae. Vertebral counts, as well as information about other osteological characters (e.g., cleithrum position, degree of development and site of articulation of posttemporal) were obtained from radiographs. Measurements of larvae follow some of those listed above, except 1) body depth, taken at posterior end of yolk inclusion (Stages B, C, D, E) or at posterior border of branchial opening (Stage F); 2) rostrum length, from its anterior tip to area where it merges with dorsal portion of head; 3) pectoral-fin length, pectoral-fin base to distal edge; 4) pectoral-fin depth, taken at its widest portion; 5) dorsal-fin fold depth, taken at its widest portion, usually at midbody; 6) ventral fin fold depth, taken at its widest portion, usually at midbody; 7) yolk-sac depth (vertically); 8) yolksac length (horizontally); and 9) yolk-sac inclusion, distance from anterior tip of area of abdominal cavity containing yolk to its posterior tip. Anatomical terminology follows Rosen \& Greenwood (1976), Gosline (1983), and Van Conner (1966) for adult specimens, and Taylor (1913) and Liem (1981) for larvae. 


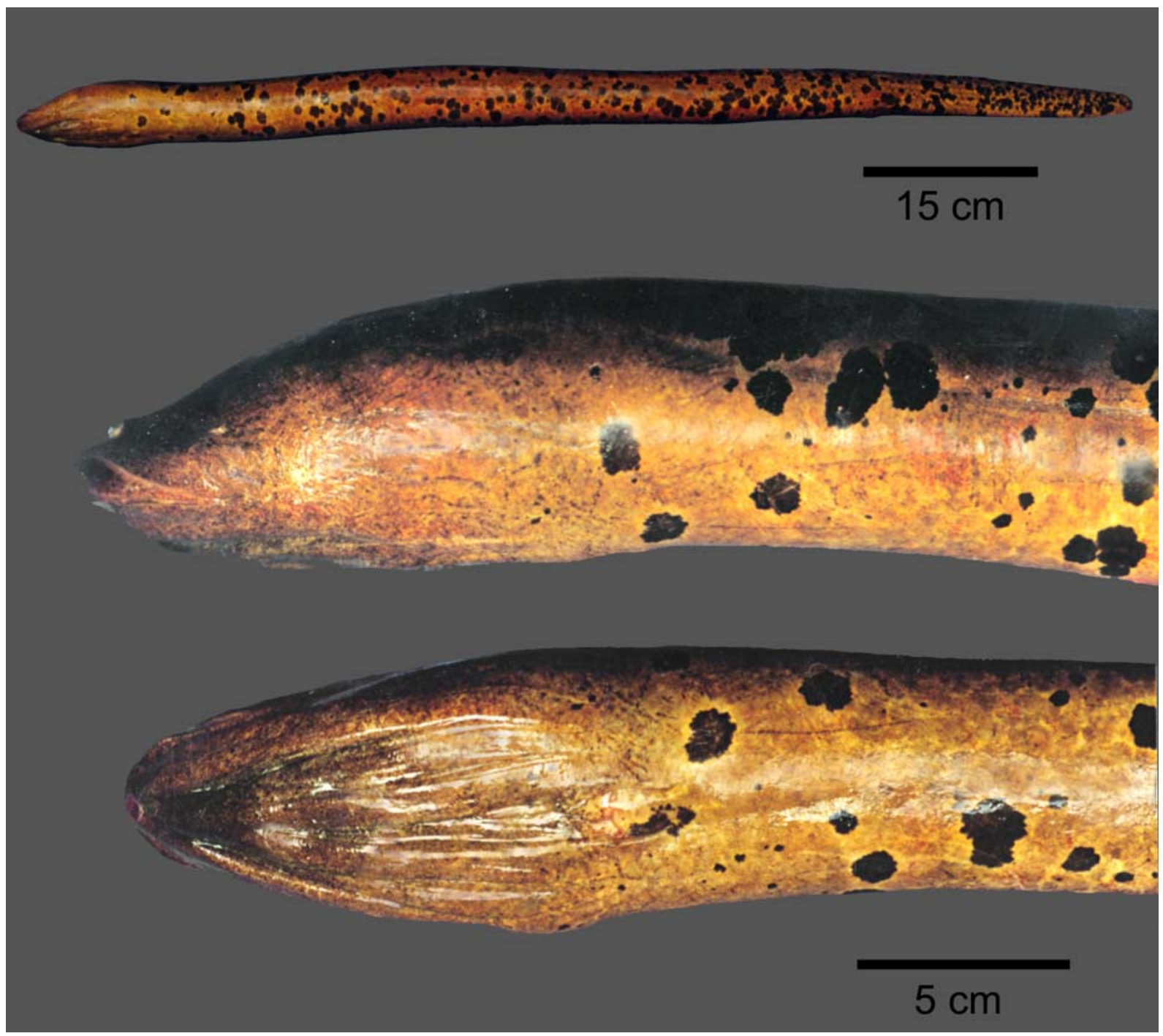

Fig. 1. Synbranchus lampreia, holotype, MZUSP 50184, 986.0 mm TL; Brazil, Pará, ilha de Marajó, rio Goiapi. General view on top, lateral view of anterior portion of body on center, and ventral view at bottom.

\section{Synbranchus lampreia, new species}

(Figs. 1, 2a)

Synbranchus sp.- Britz et al., 2003: 337-340 (larval morphology).

Holotype. MZUSP 50184 (986.0 mm TL), Brazil, Pará, ilha de Marajó, rio Goiapi, tributary of rio Arari, Cachoeira do Arari (approx. 058’S 4857’W), Nov 1995, S. E. Favorito et al.

Paratypes. All from Brazil, Pará, ilha de Marajó, rio Goiapi. MZUSP 50185 (4, 850.0-1.167,0 mm SL), same data as holotype. MPEG 3374 (1, 857.0 mm TL), Cachoeira do Arari, 20 Nov 1991, M. I. Assunção. MPEG 3377 (1, 704.0 mm TL), Taperebá, Santa Maria Farm, 23 Nov 1994, M. I. Assunção. MPEG 3379 (1, approx. $727.0 \mathrm{~mm}$ SL [tail damaged]), Cachoeira do Arari, 23 Nov 1994, M. I. Assunção. MZUSP 84453 (3 eggs, 3.9 - 4.2 mm and 46 larvae, $13.2-38.7 \mathrm{~mm} \mathrm{TL}$ ), same data as holotype.
Diagnosis. Synbranchus lampreia can be easily distinguished from S. marmoratus and S. madeirae by its color pattern which consists of conspicuous large black or dark brown, roundish blotches scattered along body, rare on head, and a relatively lighter ground coloration with small and inconspicuous light brown spots (Fig. 2a) (vs. more homogeneously distributed spots and marbled pattern in S. marmoratus (Fig. 2b) and gray uniform coloration with lighter roundish spots in $S$. madeirae). The new species can be further distinguished from S. marmoratus by its higher number of vertebrae (161-174 vs. 116-150) and higher number of caudal vertebrae (68-76 vs. 4063). Furthermore, the upper lip and the nuchal hump in $S$. lampreia is apparently less developed than in S. marmoratus. Synbranchus lampreia can be further distinguished from $S$. madeirae by its shorter post-anal length $(23.2-28.7 \%$ vs. 34.7$37.3 \%)$. 

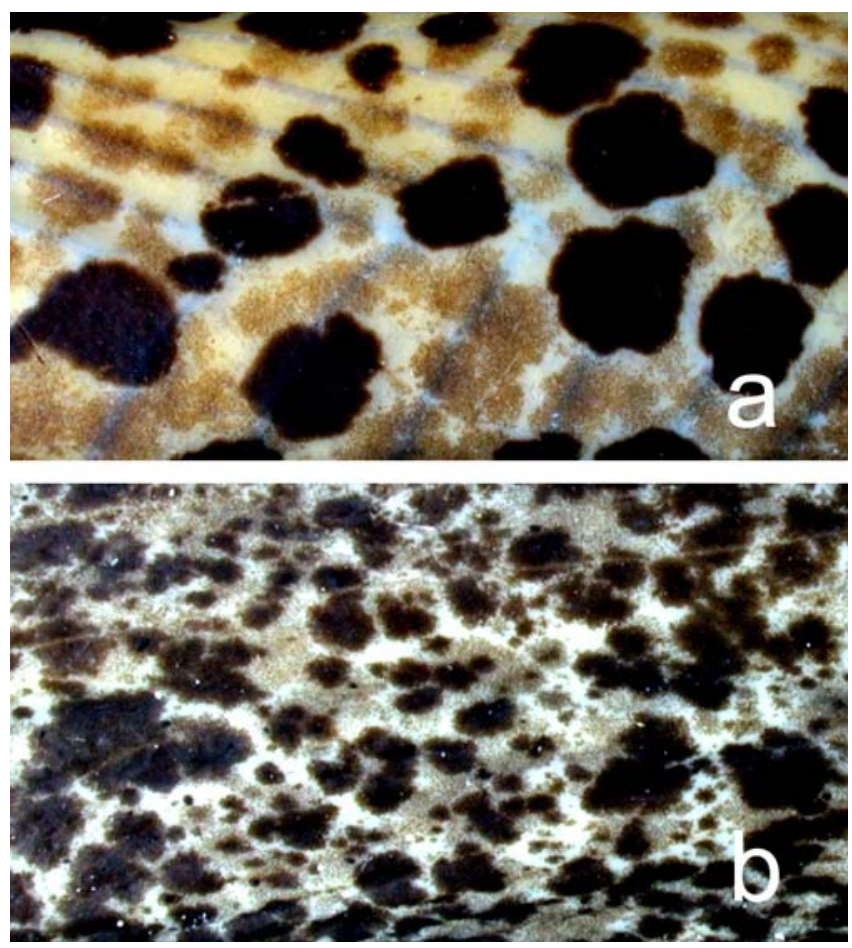

Fig. 2. Color pattern of (a) Synbranchus lampreia, MPEG 3377, 704.0 mm TL, and (b) Synbranchus marmoratus, MPEG 3375, 630.0 mm TL. Both from Brazil, Pará, ilha de Marajó, rio Goiapi.

Description. Total length of examined adult specimens 704.0 to $1167.0 \mathrm{~mm}$. Like that of other synbranchids, the body is slender and nearly straight on its dorsal and ventral margins for most of its length (Fig. 1). Greatest body depth representing 5.3-5.7\% of total length. Body relatively long, with 161 to 174 vertebrae, of which 68 to 76 are caudal, in four specimens counted. Post-anal region compressed and relatively short. Pectoral and pelvic fins absent, the former present in larvae. Anal and dorsal-fin folds vestigial; dorsal-fin fold absent on anterior third of body, extremely narrow through most of its extension and more developed on portion situated posterior to the level of anus; anal-fin fold restricted to ventral midline posterior to anus. Caudal fin absent, without rays or hypurals. Scales absent.

Head conical, rounded anteriorly. Anterodorsal profile of head slightly concave to nearly straight; relatively pointed in lateral view. Snout short. Nuchal hump moderately developed. Eyes present, well developed, visible through a translucent layer of skin, and vertically aligned to posterior nostrils. Anterior nostrils on snout tip, anteriorly positioned; posterior nostrils situated medial to eyes. Mouth opening straight. Upper and lower jaws equal in forward extension. Premaxilla with a single series of small conical teeth. Two series of teeth on dentary and ectopterygoid similar in shape but somewhat larger and stronger than premaxillary teeth. Skin fold present over premaxilla and maxilla, forming a distinct upper lip.

Lateral line absent. Three pores of laterosensory system
Table 1. Morphometric data for Synbranchus lampreia, MZUSP 50184, holotype, MZUSP 50185 ( $\mathrm{n}=4)$, MPEG 3374 $(n=1)$, MPEG $3377(n=1)$, and MPEG $3379(n=1)$.

\begin{tabular}{|c|c|c|c|c|}
\hline & Holotype & $\mathrm{n}$ & Range & Mean \\
\hline Total length $(\mathrm{mm})$ & 986.0 & 7 & $704.0-1167.0$ & - \\
\hline \multicolumn{5}{|c|}{ Percents of total length } \\
\hline Post-anal length & 24.7 & 7 & $23.2-28.7$ & 25.9 \\
\hline Head length & 10.9 & 7 & $10.0-11.5$ & 10.8 \\
\hline Head width & 4.7 & 7 & $3.6-4.9$ & 4.2 \\
\hline Body depth & 5.5 & 4 & $5.3-5.7$ & 5.5 \\
\hline \multicolumn{5}{|c|}{ Percents of head length } \\
\hline Horizontal eye diameter & 5.4 & 8 & 4.3-5.7 & 5.0 \\
\hline Preorbital length & 11.4 & 8 & $10.6-12.9$ & 11.6 \\
\hline Least interorbital width & 27.7 & 8 & 26.9-31.7 & 29.7 \\
\hline Mouth length & 39.6 & 8 & $34.3-41.8$ & 38.5 \\
\hline \multicolumn{5}{|c|}{ Percent of head width } \\
\hline Branchial opening width & 22.0 & 8 & $14.7-30.8$ & 20.7 \\
\hline
\end{tabular}

on dentary, two on preopercle, none on posttemporal or on parietal bones.

Branchial opening small, occupying less than one third of head width, restricted to central area of ventral surface of body, and nearly straight to crescent-shaped. Six completely ossified branchiostegal rays extending posteriorly and reaching vertical through cleithrum. Branchiostegal membrane forming folds between branchiostegal rays. Holobranchs well developed in four arches. First epibranchial without fossa to articulate with interarcual bone. Second and third basibranchials well developed. Third hypobranchial with long anteroventral process. First ceratobranchial close to first hypobranchial. Second ceratobranchial long, not expanded dorsally. Aerial suprapharyngeal sacs absent. Urohyal narrow and elongate, stalk-shaped. Posttemporal reduced to a lamellar and short stalk. Cleithrum not articulated with posttemporal, its dorsal tip extending upward at level of sixth abdominal vertebra, in lateral view. Afferent and efferent arteries associated with four branchial arches isolated and distinct from each other, but connected to dorsal aorta. Origin of internal carotid artery close to efferent artery of first branchial arch.

Color in alcohol. Ground color dark brown in dorsalmost portion of body and light brown laterally, becoming yellowish ventrally. Large black or dark brown, well-defined, roundish blotches scattered along body, more concentrated on ventral surface and on region posterior to anal opening. Large blotches usually restricted to region of body posterior to vertical through branchial opening (some blotches measuring around $18.0 \mathrm{~mm}$ vertically and $23.0 \mathrm{~mm}$ horizontally in holotype). Blotches becoming smaller on posterior portion of body. Small and inconspicuous light brown spots distributed among large dark blotches, forming a two colored blotched pattern (Fig. 2a). Light brown spots more conspicuous in smaller specimens and on ventral portion of body of larger individuals. These spots usually contacting each other in larger individuals, leaving just small portions of yellowish ventral ground coloration visible. Overall coloration of head similar to ground color of dorsal portion of body, without large dark blotches. Smaller specimens apparently lighter overall. 


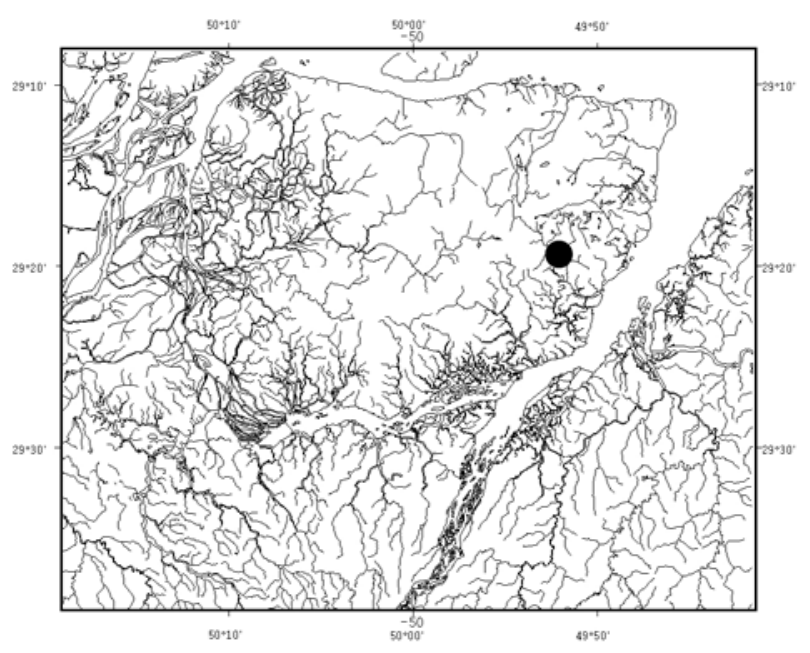

Fig. 3. Map of part of northern Brazil showing the type locality of Synbranchus lampreia. Brazil, Pará, ilha de Marajó, rio Goiapi, tributary of rio Arari, Cachoeira do Arari, approx. $0^{\circ} 58^{\prime} \mathrm{S}$ $48^{\circ} 57^{\prime} \mathrm{W}$.

Etymology. Lampréia is a portuguese word for lamprey, used by locals at ilha de Marajó to refer to this fish. Treated as noun in apposition.

Habitat and reproductive notes. Synbranchus lampreia inhabits rio Goiapi, a white water river located on the southeastern portion of ilha de Marajó, which is situated close to mouth of the Amazon river in the northeastern Pará State (Fig. 3). Ilha de Marajó, with area of $59.204 \mathrm{~km}^{2}$, is considered one of the largest fluvio-marine islands. The type locality lies within "Campos Naturais" morphoclimatic domain, covered mainly of grass vegetation, shrubs and sparse trees (Radam, 1974). This region is influenced by periodical inundations during the rainy season, that occurs between December and June, when about $70 \%$ of the area is flooded. Rio Goiapi itself floods large areas during this period but is drastically reduced (Fig. 4a), and sometimes restricted to small pools during severe droughts. Nests of S. lampreia were found in dry areas situated approximately two meters away from river margin and two meters above water level (Fig. 4a). The nests apparently are part of a gallery system which opens externally through an usually circular opening, 10 to $15 \mathrm{~cm}$ in diameter (Fig. 4b). The external aperture leads into a tunnel running vertically downwards into the soil, for approximately $30 \mathrm{~cm}$. At this point the tunnel takes a more or less horizontal direction and a floor is formed by somewhat less compact mud covered by a small pool about 2 or $3 \mathrm{~cm}$ deep, where eggs and larvae were found. Five nests contained 20 to 30 individuals each. Eggs and larvae in different stages of development were found to occur in the same nest (up to ten individuals) (e.g., stages A and F, described under 'Description of eggs and larval stages'). Nests containing larvae in different stages of development were reported for $S$. marmoratus from the Paraguayan Gran Chaco by Breder \&
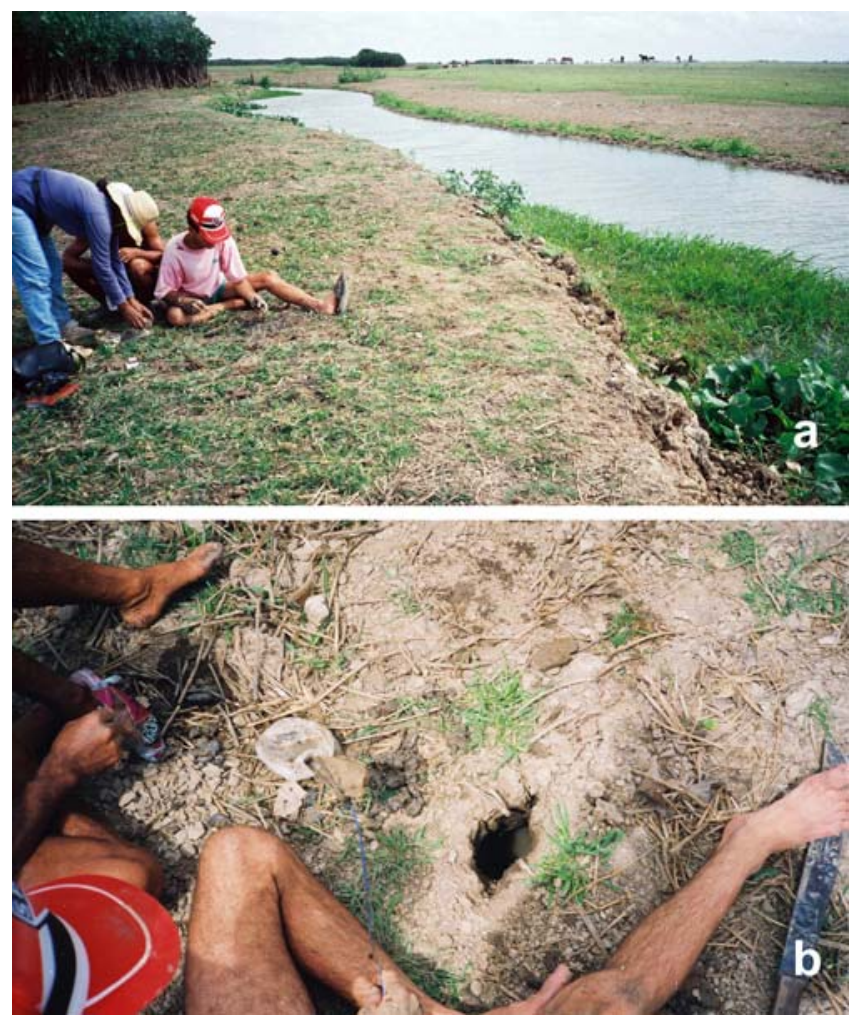

Fig. 4. Type locality of Synbranchus lampreia. (a) rio Goiapi and collecting site, and (b) burrow containing nest.

Rosen (1966:394, apud Taylor, 1913). These observations led us to suggest that $S$. lampreia eggs can be either released through many spawning activities (multiple spawning) or coexisting eggs and larvae were not necessarily offspring of the same mother (see Burt et al. (1988) for discussion about multiple spawning and Wu \& Liu (1942:3) and Breder \& Rosen (1966:395) for similar ideas in the synbranchid Monopterus albus).

An adult male was always present close to the area where eggs and larvae were found. These males showed aggressive behavior as one approached the nest, suggesting some form of male parental care. Although the direction of the horizontal branch of the gallery was not exactly defined, communication between the gallery system and the Goiapi River can be assumed. Similar nests were described previously only for Synbranchus marmoratus by Taylor (1913), based on observations in the Paraguayan Chaco.

Distribution. Known only from rio Goiapi, a tributary of rio Arari, Cachoeira do Arari, ilha de Marajó, Pará, Brazil.

Description of eggs and larval stages. Descriptions are based on 3 eggs and 46 formalin preserved larvae measuring 13.2$38.7 \mathrm{~mm}$ TL (Figs. 5, 6, Table 2). Six larval stages were defined based on the degree of development of morphological characters visible externally such as pectoral fin, rostrum, and yolk inclusion. We tried to match the stages of Synbranchus lampreia with those described and illustrated by Taylor (1913) 

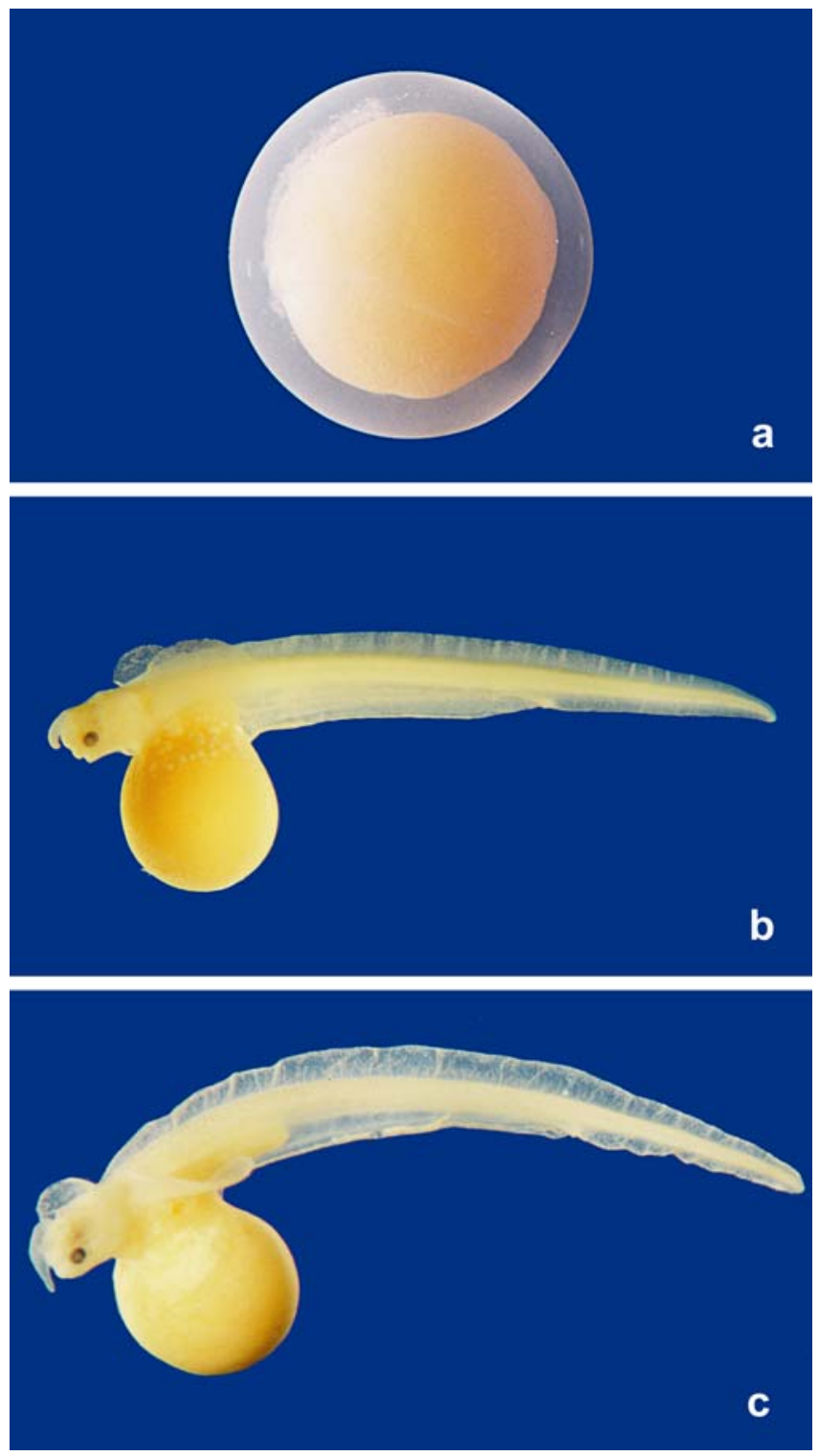

Fig. 5. Eggs and larval stages of Synbranchus lampreia. (a) egg in Stage A; (b) larva in Stage C; (c) larva in Stage D, general view.

for $S$. marmoratus. The length of some measurements in the larvae we described are longer than those of $S$. marmoratus, a fact probably related to the relative larger size of the adults of S. lampreia (704.0-1167.0 mm TL versus maximum TL of $857.0 \mathrm{~mm}$ in S. marmoratus).

Stage A. Two spherical eggs (diameter $=4.1$ and $4.2 \mathrm{~mm}$ ) with embryos not visible externally (Fig. 5a). The eggs consist of a firm and somewhat tough capsule separated from the yolk by the perivitelline space. A mass of what looks like a coagulated albuminous substance is present at the vegetative pole, similarly to that described for eggs of $S$. marmoratus by Taylor (1913:4). This stage probably corresponds to Taylor's (1913:7) Stage 17 with a germinative pole containing a Y-shaped white line of $1.9 \mathrm{~mm}$ (compare with Taylor's fig. 4).
Stage B. One egg $($ diameter $=3.9 \mathrm{~mm})$ with the embryo clearly visible through the egg capsule. At this stage there is a proboscis-like structure projecting freely from anterior end of larva (see Taylor's fig.7, 1913). This rostrum is transparent, bluntly pointed and filled apparently with a clear fluid without any apparent cellular elements (see Figs. 5b-c and 6a,b showing rostrum in Stages $\mathrm{C}$ to $\mathrm{E}$ ). Eyes are not visible at this stage. The tail of the embryo is curled, though still in contact with the yolk. The pectorals and the unpaired larval dorsal and anal median fin folds are already visible under the capsule and are also curled. They extend as relatively translucent membranes of skin from the point of pectoral-fin insertion to the posterior tip of the curled tail. The depth of larval dorsal and anal fin folds are similar, and equivalent to body depth. Distance from anterior tip of rostrum to anterior end of encephalon $0.95 \mathrm{~mm}$, from anterior tip of rostrum to pectoral-fin insertion $2.5 \mathrm{~mm}$, pectoral-fin length $3.3 \mathrm{~mm}$. Stage B described herein probably corresponds to Taylor's Stage 23 (1913).

Stage C. Three hatched embryos with main portion of body completely free from yolk sac and without significant yolk included in abdominal cavity (Fig. 5b). After intermediate stage of hatched and coiled embryo, between Stage B and C not documented herein, the coiled portion of body straightens out as the embryo grows, so that at stage $\mathrm{C}$ a straight line joining tip of rostrum to tip of tail measures $13.2-15.3 \mathrm{~mm}$. The rostrum has lengthened and lies curled in parallel with the curve of the yolk-sac. Although without clearly defined pigmentation, a large and laterally positioned eye is visible. The mouth is well defined and the opercular opening is clearly visible. Larval anal-fin fold somewhat deeper than dorsal-fin fold, its depth measuring $0.5 \mathrm{~mm}$ in the area close to the yolksac. Segmentation of musculature clearly visible. Probably correspond to or is slightly more developed than Taylor's Stage 26 (1913:11, fig. 9).

Observations of live larvae at this stage, and the next two stages, showed a dense network of capillaries in the pectoral fins. Active movements of these fins propelled water from a well-circumscribed area anterodorsal around the head to the posterior portion along the length of the entire larva and its yolk sac. These pectoral fin movements were previously described for larvae of Synbranchus marmoratus (Taylor, 1913:15), Monopterus cuchia (Banerj et al., 1981:149; Munshi et al., 1989a:310), and Monopterus albus (Wu \& Liu, 1942:6; Liem, 1981:1177). According to Liem, synbranchid larvae can survive periods of critical hypoxia because they have a combination of adaptations, including highly vascularized pectoral fins and other large vascularized areas of body, an active pectoral fin mechanism that generates a posteriorly directed respiratory water current originating from the oxygen-rich surface layer, allied with a small blood-water barrier, and a principal flow of blood that runs in form of a countercurrent to the water stream. As described in item "Habitat and reproductive notes" eggs and larvae of S. lampreia were collected in 2 or $3 \mathrm{~cm}$ small and poorly oxygenated pools, located distant from stream water. Presence of pectoral fins is restricted 

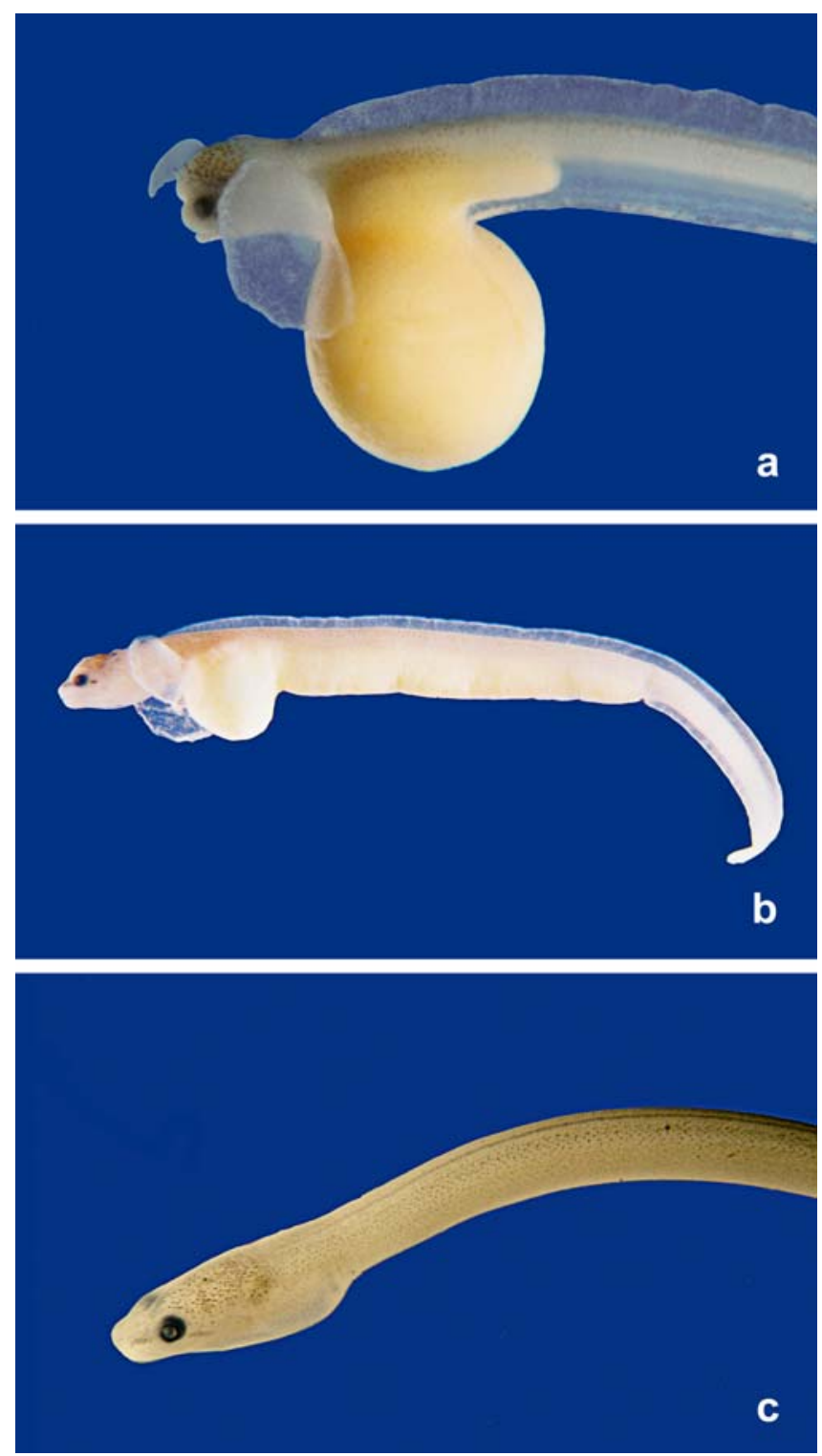

Fig. 6. Eggs and larval stages of Synbranchus lampreia. (a) anterior portion of larva in Stage D; (b) larva in Stage E, and (c) anterior portion of juvenile in Stage F.

to stages described herein as C, D and E, being completely absent in Stage " $F$ " when the branchial chamber has the respiratory function.

Stage D. Eleven larvae (15.1-19.6 mm TL) with a certain degree of yolk inclusion in their abdominal cavities (Fig. 5c and 6a). Although assigned to just a single stage, these larvae show some variation in the amount of egg inclusion and in rostrum size and position. Largest portion of rostrum (2/3) situated over head and smaller anterior portion (1/3) is hanging free anterior to head; rostrum terminal in the smaller specimens (those with less amount of included yolk) becoming shorter and more anterodorsally positioned in larger specimens. Myomeres well defined. Demarcation line between dorsal and ventral musculature visible as a longitudinal sulcus. Dorsal larval fin fold apparently deeper in smaller specimens, becoming narrower in larger ones. Pectoral fin similar to that described in the previous stage, although comparatively larger. Dark chromatophores are present on dorsal portion of head and body, starting immediately posterior to rostrum and becoming densely concentrated in a horizontal stripe along dorsal-fin fold base. Eyes pigmented. Probably corresponds to Taylor's Stage 30 (1913:15, fig. 10).

Stage E. Ten larvae (4 measured, 21.5-23.9 mm SL) with large amounts of yolk enclosed in the abdominal cavity (Fig. 6b). The yolk enclosed in the embryo's body extends to within 1.0 $\mathrm{mm}$ of the anus in larger specimens examined and has total extension of about 11.5-15.2 mm. The yolk sac has almost lost its globular appearance. Rostrum very reduced, absent as a free structure and tied to the dorsal portion of the head. Pectoral fin reduced in proportion to rest of body and more ventrally positioned. Anal larval fin fold restricted to portion of body posterior to anal opening. Post-anal portion somewhat curled ventrally.

At this stage the larvae are more densely pigmented. Dorsal and lateral surfaces of head with inconspicuous dark chromatophores, reaching approximately the horizontal through center of eye and continuing dorsally and posteriorly through dorsal-fin fold base. Lateral and ventral portion of body and fins with sparsely distributed dark chromatophores. Presence of conspicuous and horizontally elongated dark stripe, starting anterior to eye and continuing posteriorly beyond it for an extension approximately equal to eye diameter. Probably corresponds to Taylor's Stage 32 (1913:16, fig. 13).

Stage F. Twenty-two specimens with body shape similar to adults (35.0-38.7 mm TL) (Fig. 6c). The specimens are eel-like shaped, the body behind opercular cavity being almost perfectly cylindrical, while the posterior part of the trunk becomes gradually laterally compressed and merges into the tail. There is no vestige of pectoral fins and no trace of rostrum. The yolk sac is completed absorbed. Lateral portion of branchial opening completely closed with single aperture limited to ventral portion of body. Chromatophores are still more conspicuous on the dorsal and lateral portions of head and body where they are situated close to the skin surface. Dark stripe anterior to eye still present. Chromatophores situated on ventral half of body inserted deeply in skin, giving a faded appearance to pigmentation. Chromatophores situated on lateral portion of body arranged along the segmented limits of the V-shaped myomeres. Ventral midline without pigmentation. Corresponds to Taylor's Stage 35 (1913:18, fig. 16).

\section{Discussion}

As mentioned in the introduction, Synbranchus taxonomy is still confuse. Examination of a large number of specimens of $S$. marmoratus by Favorito-Amorin $(1992,1998)$ revealed difficulties in characterizing the species in light of the highly 
Table 2. Morphometrics of larval stages of Synbranchus lampreia, MZUSP 84453. All measurements are expressed in $\mathrm{mm}$. Ranges for each measuring are followed by (n).

\begin{tabular}{|c|c|c|c|c|}
\hline & Stage C & Stage D & Stage E & Stage F \\
\hline Total length & $\begin{array}{c}13.2-15.3 \\
\text { (3) }\end{array}$ & $\begin{array}{c}15.1-19.6 \\
(9)\end{array}$ & $\begin{array}{c}21.5-23.9 \\
\text { (4) }\end{array}$ & $\begin{array}{c}35.0-38.7 \\
\text { (6) }\end{array}$ \\
\hline Post-anal length & $\begin{array}{c}9.3-10.6 \\
\text { (3) }\end{array}$ & $\begin{array}{c}9.9-12.8 \\
\text { (9) }\end{array}$ & $\begin{array}{c}13.5-15.7 \\
\text { (4) }\end{array}$ & $\begin{array}{c}12.1-13.4 \\
\text { (6) }\end{array}$ \\
\hline Body depth & $\begin{array}{l}0.5 \\
(3)\end{array}$ & $\begin{array}{c}0.5-0.8 \\
(9)\end{array}$ & $\begin{array}{c}0.7-0.8 \\
\text { (4) }\end{array}$ & $\begin{array}{c}1.4-1.8 \\
(6)\end{array}$ \\
\hline Head length & - & - & - & $\begin{array}{c}4.9-5.5 \\
(6)\end{array}$ \\
\hline Rostrum length & $\begin{array}{c}0.9-1.2 \\
\text { (3) }\end{array}$ & $\begin{array}{c}0.6-1.4 \\
(9)\end{array}$ & $\begin{array}{l}0.6-0.8 \\
(4)\end{array}$ & - \\
\hline Pre-orbital length & - & - & - & $\begin{array}{l}0.7-0.8 \\
(6)\end{array}$ \\
\hline Horizontal eye diameter & - & - & - & $\begin{array}{c}0.6-0.7 \\
(6)\end{array}$ \\
\hline Mouth length & - & - & - & $\begin{array}{c}1.2-1.5 \\
(6)\end{array}$ \\
\hline Pectoral-fin length & $\begin{array}{l}2.2 \\
(2)\end{array}$ & $\begin{array}{c}2.3-3.2 \\
(9)\end{array}$ & $\begin{array}{c}2.4-2.7 \\
(3)\end{array}$ & - \\
\hline Pectoral-fin depth & $\begin{array}{l}1.5 \\
(1)\end{array}$ & $\begin{array}{c}1.1-2.1 \\
(9)\end{array}$ & $\begin{array}{c}1.0-1.6 \\
(2)\end{array}$ & - \\
\hline Dorsal-fin fold depth & $\begin{array}{c}0.3-0.5 \\
(3)\end{array}$ & $\begin{array}{c}0.5-0.7 \\
(9)\end{array}$ & $\begin{array}{c}0.4-0.7 \\
(4)\end{array}$ & $\begin{array}{l}0.2-0.4 \\
(6)\end{array}$ \\
\hline Ventral-fin fold depth & $\begin{array}{l}0.4-0.5 \\
\text { (3) }\end{array}$ & $\begin{array}{l}0.4-0.6 \\
(9)\end{array}$ & $\begin{array}{l}0.2-0.4 \\
\text { (4) }\end{array}$ & $\begin{array}{l}0.2 \\
(6)\end{array}$ \\
\hline Yolk-sac depth & $\begin{array}{c}3.6-3.8 \\
\text { (3) }\end{array}$ & $\begin{array}{c}2.9-3.1 \\
(8)\end{array}$ & $\begin{array}{c}2.4-3.0 \\
(4)\end{array}$ & - \\
\hline Yolk-sac length & $\begin{array}{c}3.2-3.6 \\
(3)\end{array}$ & $\begin{array}{c}2.6-3.1 \\
(9)\end{array}$ & $\begin{array}{c}2.4-2.7 \\
(4)\end{array}$ & - \\
\hline Yolk inclusion length & $\begin{array}{c}0 \\
(3)\end{array}$ & $\begin{array}{c}4.1-1.2 \\
(9)\end{array}$ & $\begin{array}{c}11.5-15.2 \\
\text { (4) }\end{array}$ & - \\
\hline
\end{tabular}

variable morphological and meristic characters as well as patterns of coloration throughout its broad distribution. Cytogenetic studies also revealed a number of cytotypes found in specimens identified as $S$. marmoratus, reinforcing the possibility that several species are currently hidden under that name (Melillo et al., 1996; Torres et al., 2005). In addition, $S$. marmoratus was suggested as a non- monophyletic group in the molecular phylogeny of Synbranchus and Ophisternon proposed recently by Perdices et al. (in press). The redefinition of S. marmoratus, although necessary, is beyond the scope of the present study. In spite of the variation pointed out above, it is relatively easy to distinguish the forms usually identified as $S$. marmoratus from $S$. madeirae, the second known species up to date. Some of the characters utilized by Rosen \& Rumney (1972:12) in their diagnosis of $S$. madeirae, such as higher total number of vertebrae, long caudal peduncle, and dorsal tip of cleithrum at level of fifth or sixth vertebra clearly separates this species from $S$. marmoratus. Although the cited characters are also useful to differentiate $S$. marmoratus from S. lampreia, they are shared by $S$. lampreia and $S$. madeirae. As partially stated in the "Diagnosis", these two species can be distinguished mainly on the basis of a different color pattern, range of post-anal length, and larger maximum size of S. lampreia.

Synbranchus madeirae is known only from the type series caught in the Upper Madeira drainage (Rosen \& Greenwood, 1976). The examination of hundreds of Synbranchus specimens deposited in various collections around the world, including specimens from the rio Madeira basin (FavoritoAmorin, 1992,1998; this study), revealed no additional specimens of S. madeira. Thus, the distribution pattern of the Synbranchus species apparently comprises a widely distributed "species" from Mexico to north of Argentina $(S$. marmoratus), and other two species ( $S$. madeirae and $S$. lampreia) with apparently restricted geographical occurrence. Recognized undescribed species of Synbranchus to be published elsewhere also have restricted distributions, fitting into the pattern described above.

As already noted, the type locality of S. lampreia is subject to periodical floods and its eggs and larvae were captured during dry season. At this period of the year (early November) the Goiapi river is restricted to its main channel and the marginal banks are exposed (Fig. 4a). The eggs of $S$. lampreia are probably laid during favorable periods in between floods, possibly close to the end of the dry season, since the rainy season started days after the end of the collecting field trip. As already described, these eggs were found in small pools $2-3 \mathrm{~cm}$ deep and larval survival in hypoxic conditions is possible due to the series of adaptations involving presence of pectoral fins, blood countercurrent with respect to water stream, and highly vascularized areas of body (see under Stage C of 'Description of eggs and larval stages'). After passing through the first stages of development in poorly oxygenated waters, the rainy period starts soon after (late November or December) and the juveniles reach oxygenated and flowing water. A close temporal relationship between rain regime and reproductive strategies seems to be characteristic of $S$. lampreia. Seasonal variation related to the reproductive period of $S$. marmoratus from Panama was also suggested by Breder (1927), but with spawning occurring late in the rainy season.

Our field observations revealed the presence of an adult male always close to the area where the eggs and larvae were deposited, indicating some sort of parental care in Synbranchus lampreia. Evidence of male parental care in synbranchids in general was summarized by Breder \& Rosen (1966:394) and Blumer (1982:5) and cited specifically for $S$. marmoratus by Taylor (1913:3). According to Blumer (1982:5), nest building and/or substrate cleaning, along with guarding of eggs are forms of parental care recorded for the family, and likely to occur in S. lampreia. Duration of parental care activities was reported only in the synbranchid Monopterus albus, in which the male guards the eggs until the larvae are able to care for themselves (Breder \& Rosen, 1966:395).

Reproductive strategies among fishes have been currently defined as 'periodic', 'opportunistic', 'equilibrium', and 'intermediate' strategies (Winemiller \& Rose, 1992:2210). These strategies are identified mainly on the basis of several lifehistory parameters such length at maturation, spawning frequency, duration of spawning season, clutch size, egg size, larval growth rate, and extent of parental care. Although few of these parameters are known for Synbranchus lampreia, we observed a large body size, apparent seasonal spawning, 
small clutches characterizing low fecundity, large eggs, possible multiple spawning and male nest guarding for the species. Synbranchus lampreia shares with the periodic strategists spawning apparently coinciding with favorable periods within the temporal cycle of the environment. However, relative to the periodic strategists which are characterized also by having small eggs, large clutches, and high fecundity, $S$. lampreia appears to have adopted a more equilibrium strategy of greater investment in larger eggs, fewer offspring, and development of parental care. More detailed information about life-history aspects of S. lampreia is necessary, as well for the remaining Synbranchiformes, but the data gathered so far characterize $S$. lampreia as having an intermediate strategy, in between the periodic and equilibrium strategies.

Comparative material examined. Synbranchus madeirae: AMNH 30214, 4 paratypes, 93-141 mm TL; Beni, between Nuevo Berlin and Mayo Mayo, río Mamoré. Synbranchus marmoratus: Brazil. Pará State: MPEG 3375, 3, 520-630 mm TL; ilha de Marajó, Cachoeira do Arari, Taperebá, Santa Maria Farm, rio Goiapi. MPEG 3381, 350, mm TL; MPEG 2150, 857, mm TL; MPEG 3338, 823 mm TL; MPEG 3382, 2, 637-656 mm TL; ilha de Marajó, Cachoeira do Arari, rio Goiapi. MZUSP 42546, 246 mm TL; rio Gurupi, Canindés. MZUSP 42554, 448 mm TL; rio Guamá. MZUSP 42536, 439 mm TL; Breves. USNM 200300, 168 mm TL; Utinga. Amazonas State: MPEG 861, 4, 262-340 mm TL; Supiã-pucu, rio Tefé. MZUSP 5850, $210 \mathrm{~mm}$ TL; lago Capitari, rio Madeira.

\section{Acknowledgments}

We are grateful to Naércio Aquino Menezes and Flávio C.T. Lima for their comments and suggestions on the manuscript. Horácio Higuchi's hospitality and assistance during a visit to Museu Goeldi are also gratefully acknowledged. The museum technician Alberto Souza assisted with field work in Belém and Jaime Júnior with live specimens. Eduardo Baena helped with photography editing and Cristiano Moreira produced the map. Thanks also to Ralf Britz and an anonymous reviewer for their valuable comments.

\section{Literature Cited}

Bailey, R. M. \& C. Gans. 1998. Two new synbranchid fishes, Monopterus roseni from Peninsular India and M. desilvai from Sri Lanka. Occasional Papers of the Museum of Zoology, University of Michigan, 726:1-18.

Banerji, S.R., M. I. Singh \& N. K. Thakur. 1981. Observations on natural breeding and larval development of the common mud-eel Amphipnous cuchia. Hydrobiologie, 79:147155.

Blumer, L. S. 1982. A bibliography and categorization of bony fishes exhibiting parental care. Zoological Journal of the Linnean Society, 76:1-22.

Breder, C. M. Jr. 1927. The fishes of the Rio Chucunaque drainage, eastern Panama. Bulletin of the American Museum of Natural History, 57:91-176.
Breder, C. M. Jr. \& D. E. Rosen. 1966. Modes of Reproduction in Fishes. Garden City, New York: Natural History Press.

Britz, R., S. Favorito \& G. D. Johnson. 2003. The hyopalatine arch of a $25 \mathrm{~mm}$ larva of Synbranchus and homology of the single pterygoid in the Synbranchidae (Teleostei: Synbranchiformes). Proceedings of the Biological Society of Washington, 116(2):337-340.

Burt, A., D. L. Kramer, N. Nakatsuru \& C. Spry. 1988. The tempo of reproduction in Hyphessobrycon pulchripinnis (Characidae), with a discussion on the biology of 'multiple spawning' in fishes. Environmental Biology of Fishes, 22(1):15-27.

Favorito-Amorim, S. E. 1992. Revisão sistemática das espécies brasileiras do gênero Synbranchus (Teleostei: Acanthopterygii). Unpublished MSc thesis, Universidade de São Paulo, São Paulo. 84 p.

Favorito-Amorim, S. E. 1998. Relações filogenéticas da ordem Synbranchiformes e revisão sistemática da família Synbranchidae (Teleostei: Acanthopterygii). Unpublished $\mathrm{PhD}$ dissertation, Universidade de São Paulo, São Paulo. $268 \mathrm{p}$.

Gosline, W. A. 1983. The relationships of the mastacembelid and synbranchid fishes. Japanese Journal of Ichthyology, 29:323-328.

Liem, K. F. 1981. Larvae of air breathing fishes as countercurrent flow devices in hypoxic environments. Science, Washington, 211:1177-1179.

Liem, K. F. 1987. Functional design of the air ventilation apparatus and overland excursions by teleosts. Fieldiana, 1379:1-29.

Lo Nostro, F. \& G. Guerrero. 1996. Presence of primary and secondary males in a population of Synbranchus marmoratus, Bloch 1795, a protogynous fish (Teleostei Synbranchiformes). Journal of Fish Biology, 49:788-800.

Melillo, I. F. M., F. Foresti \& C. Oliveira. 1996. Additional cytogenetic studies on local populations of Synbranchus marmoratus (Pisces, Synbranchiformes, Synbranchidae). Naturalia, 21:201-208.

Munshi, J. S. D., P. K. Roy \& S. S. T. Nasar. 1989a. Oxygen uptake capacity of larval respiratory organs of air-breathing swamp mud eel, Monopterus cuchia (Ham.): a morphometric study. Proceedings of the Indian National Science Academy, B55:309-315.

Munshi, J. S. D., G. M. Hughes, P. Gehr \& E. R. Weibel. 1989b. Structure of the air-breathing organs of a swamp mud eel, Monopterus cuchia. Japanese Journal of Ichthyology, 35:453-465.

Nelson, J. S. 1994. Fishes of the World. John Wiley \& Sons, New York, $600 \mathrm{pp}$.

Perdices, A., I. Doadrio \& E. Berminghan. 2005. Evolutionary history of the synbranchid eels (Teleostei: Synbranchidae) in Central and the Caribbean islands inferred from their molecular phylogeny. Molecular Phylogenetics and Evolution, in press.

RadamBrasil. 1974. Projeto RadamBrasil. Levantamento de recursos naturais. Belém, v. 5, fol. 5A. 22. 
Rangarajan, K. \& J. Jacob. 1960. On the development of the eel-like fish Synbranchus bengalensis. Journal of the Zoological Society of India, 12:147-151.

Ravaglia, M. A., F. Lo Nostro, M. C. Maggese, G. A. Guerrero \& G. M. Somoza. 1997. Characterization of molecular variants of GnRH, induction of spermiation and sex reversal using salmon GnRH-A and domperidone in the protogynous diandric fish, Synbranchus marmoratus Bloch (Teleostei, Synbranchidae). Fish Physiology and Biochemistry, 16:425-436.

Rosen, D. E. \& A. Rumney. 1972. Evidence of a second species of Synbranchus (Pisces, Teleostei) in South America. American Museum Novitates, (2497): 1-45.

Rosen, D. E. \& P. H. Greenwood. 1976. A fourth neotropical species of synbranchid eel and the phylogeny and systematics of synbranchiform fishes. Bulletin of the American Museum of Natural History, 157(1): 1-70.

Sadovy, I. \& D. Shapiro. 1987. Criteria for the diagnosis of hermaphroditism in fishes. Copeia, 1987(1): 136-156.

Tao, Y., H. Lin, G. Van Der Kraak \& R. Peter. 1993. Hormonal induction of precocious sex reversal in the rice field eel, Monopterus albus. Aquaculture, 118: 131-140.

Taylor, M. 1913. The development of Synbranchus marmoratus. Quarterly Journal of Microscopical Science, 233:1-52.
Torres, R. A., J. J. Ropert, F. Foresti \& C. Oliveira. 2005. Surprising genomic diversity in the Neotropical fish Synbranchus marmoratus (Teleostei: Synbranchidae): how many species?. Neotropical Ichthyology, 3(2):277284.

Tyler, J. C. \& I. C. Feller. 1996. Caribbean marine occurrence in mangroves of a typical fresh-water synbranchiform fish. Gulf of Mexico Sciences, 14(1):26-30.

Van Conner, J. 1966. Morphology of the neotropical swamp eel, Synbranchus marmoratus (Pisces: Teleostei), with emphasis on adaptive features. MSc dissertation, Texas A \& M University, College Station, Texas. 94p.

Winemiller, K. O. \& K. A. Rose. 1992. Patterns of life story diversification in North American fishes: implications for population regulation. Canadian Journal of Fisheries and Aquatic Sciences, 49(10):2196-2218.

Wu, H. W. \& C. K. Liu. 1942. On the breeding habits and the larval metamorphosis of Monopterus javanensis. Sinensia, 13: $1-13$.
Received April 2005

Accepted August 2005 